\title{
Use of the Metal Deletion Technique for Radiotherapy Planning in Patients with Cardiac Implantable Devices
}

\author{
Použití metody Metal Deletion Technique pro odstraňování \\ artefaktů při plánování radioterapie u pacientů s implantovanými \\ kardiostimulátory
}

\author{
Odlozilikova A. ${ }^{1,2}$, Kurzyukova A. ${ }^{3}$, Sepsi M. ${ }^{4}$, Pospisil D. ${ }^{4}$, Slampa P., \\ 1 Department of Radiation Oncology, Faculty of Medicine, Masaryk University, Brno \\ 2 Department of Radiation Oncology, Masaryk Memorial Cancer Institute, Brno \\ ${ }^{3}$ Ural Federal University named after the first President of Russia B. N. Yeltsin, Yekaterinburg, Russia \\ ${ }^{4}$ Department of Internal Medicine and Cardiology, University Hospital Brno
}

\begin{abstract}
Summary
Background: The number of cancer patients with cardiac implantable electronic devices receiving radiotherapy is increasing. Irradiation of such patients can cause malfunctions in pacemakers and implantable cardioverter-defibrillators. In this respect, it is necessary to make a proper irradiation plan for such cancer patients to minimize the dose received by both cardiac devices and pacing leads. However, planning computed tomography (CT) scans have metal artifacts that degrade the image quality and make it difficult to create a qualitative radiation plan. In fact, there is a problem of correct contouring not only of critical organs and planning target volume, but also of cardiac devices and pacing leads during the planning of CT scan operations. Patients and methods: To analyze this issue, we tested the Metal Deletion Technique (MDT) on nine cancer patients with different tumor localizations near cardiac implantable electronic devices and device types who were treated at the Masaryk Memorial Cancer Institute. We conducted a radiotherapy planning in Eclipse ${ }^{\mathrm{TM}}$ Treatment Planning System, version 11.0 (Varian, Palo Alto, Canada) (employing three-dimensional conformal radiation therapy, intensity-modulated radiation therapy, volumetric-modulated arc therapy and stereotactic body radiation therapy irradiation techniques). We analyzed the influence of MDT on plan parameters and compared CT scans without and with application of the MDT method. Results: The results confirm the need to use the MDT method for reduction the likelihood of malfunctions in devices. The greatest error in determining the dose received by implantable devices and pacing leads is more than $3 \%$ of the total dose. It can significantly change the patient's treatment plan. Conclusion: The data obtained in this experiment are crucial for physicists when selecting radiation techniques and suitable methods for planning the irradiation of patients with implantable electronic devices.
\end{abstract}

Key words

radiation therapy - cardiac devices - Metal Deletion Technique - artifacts - quality improvement
The work was supported by grant MH CZ-DRO (MMCl, 00209805).

Tato práce byla podpořena grantem MH CZ-DRO (MMCl, 00209805).

The authors declare they have no potential conflicts of interest concerning drugs, products, or services used in the study.

Autor̆i deklarují, že $v$ souvislosti s predmětem studie nemaji žádné komerční zájmy.

The Editorial Board declares that the manuscript met the ICMJE recommendation for biomedical papers.

Redakční rada potvrzuje, že rukopis práce splnil ICMJE kritéria pro publikace zasílané do biomedicínských časopisů.

Ing. Anna Odložilíková, Ph.D.

Department of Radiation Oncology Masaryk Memorial Cancer Institute Zluty kopec 7

65653 Brno

e-mail: odlozilikova@mou.cz

Submitted/Obdrženo: 4. 9. 2018 Accepted/Príijato: 21. 10. 2018

doi: $10.14735 / a m k o 2018434$ 


\section{Souhrn}

Východiska: Počet onkologických pacientů s implantovanými kardiostimulátory indikovaných k radioterapii se stále zvyšuje. Ozařování těchto pacientů může způsobit selhání některých funkcí kardiostimulátorů a kardioverter-defibrilátorů. Proto je nutné vypracovat pro tyto pacienty ozařovací plány s minimalizací dávky na implantované kardiovaskulární elektronické zařízení a stimulační elektrody. Bohužel kvalita plánovacích CT řezů je zhoršená vlivem artefaktů způsobených metalickými částmi samotného implantátu a toto ztěžuje vypracování kvalitního ozařovacího plánu. Hlavním problémem pro radioterapeuta a plánujícího radiologického fyzika je správné zakonturování kritických orgánů, plánovacího cílového objemu a samotného kardiostimulátoru se stimulačními elektrodami. Soubor pacientů a metody: Na Klinice radiační onkologie Masarykova onkologického ústavu byla provedena analýza vlivu techniky Metal Deletion Technique (MDT) na odstranění artefaktu u devíti pacientů s různou lokalizací tumoru v těsné blízkosti implantovaného kardiostimulátoru (mamma, jícen, plíce, hlava/krk). Ozařovací plány byly vypracovány v plánovacím systému Eclipse ${ }^{\mathrm{T} M}$, verze 11.0 (Varian, Palo Alto, Canada) $\mathrm{s}$ využitím technik three-dimensional conformal radiation therapy, intensity-modulated radiation therapy, volumetric-modulated arc therapy a stereotactic body radiation therapy. Byly porovnány parametry plánů vypracovaných s použitím MDT techniky i bez ní. Výsledky: Výsledky studie potvrzují vhodnost použití této metody pro odstraňování artefaktů u pacientů s implantovanými kardiostimulátory. Největší chyba ve výpočtu dávky obdržené kardiostimulátorem a elektrodou bez použití MDT metody překročila $3 \%$ z celkové dávky. Tyto údaje mohou značně ovlivnit ozařovací plán. Závěr: Data získaná z tohoto experimentu jsou významná pro radiologické fyziky při výběru vhodné techniky ozařování pacientů s implantovaným elektronickým zařízením.

Klíčová slova

radioterapie - kardiovaskulární elektronické zařízení - Metal Deletion Technique - artefakty - zvyšování kvality

\section{Introduction}

The rapid development of radiation therapy technologies enhances the quality of irradiation for cancer patients. Nowadays, a large number of cancer patients have cardiac implantable electronic devices (CIEDs), such as pacemakers (PMs) and implantable cardioverter-defibrillators (ICDs), which consist of a metal case, microchip and battery, and can stimulate the cardiac muscle $[1,2]$. ICDs incorporate both PM functions and its ability to produce a high-voltage shock to terminate potentially lethal cardiac arrhythmia. Although most medical treatments pose a little danger to CIEDs, radiotherapy is capable of altering their functions, and can lead to a complete loss of their capacity [3]. It is impossible to predict the exact operation of CIEDs when they are used during radiotherapy or right after the treatment $[4,5]$. Due to new technological elements, modern devices are more resistant to ionizing radiation. However, this stability differs for various types of electronic devices and their manufacturers. Moreover, not all manufacturers indicate the maximum dose of acceptable radiation for their devices. Nevertheless, in any case, radiological physicists should attempt to reduce the dose received by PMs/ICDs and leads.

In this respect, it is necessary to make a proper irradiation plan for such cancer patients to minimize the dose value. However, the plan may be hindered since planning computed tomography (CT) scans have metal artifacts that degrade the image quality. Thus, there is a need for methods reducing these artifacts, among which the Metal Deletion Technique (MDT) is tested in this survey.

In fact, there is a problem of correct contouring not only of critical organs and planning target volume (PTV), but also of cardiac devices and pacing leads during the planning of CT scan operations. The thing is that metal implants can cause gray streaks (artifacts) apart from regular white fields seen on a CT scan and corresponding to metals on the Hounsfield scale (about 1,000 Hounsfield units). Apparently, it hinders the identification of vital organs and tumor areas. Moreover, artifacts make it harder to calculate the right dose received by CIEDs.

\section{Patients and methods}

Artifacts are mostly caused by the fact that filtered back projection used in $\mathrm{CT}$ image reconstruction suggests each of X-ray detector measurements is equally accurate. In fact, X-rays passed through or next to metal implants are severely attenuated and inaccurate. The MDT method eliminates these inaccuracies and restores non-metallic parts of a CT image in high quality [6]. Then, metal-concerned data are processed. As a result, the image of a higher quality is produced. In the study, the MDT was used as a software available in Masaryk Memorial Cancer Institute.
We tested the MDT on 9 of 15 cancer patients at the Masaryk Memorial Cancer Institute who were implanted with cardiac electronic devices (54\% with PMs and $46 \%$ with ICDs), and diagnosed with tumor localized in breast, prostate, esophagus, head/neck and lungs. In most cases, the location of cancer (except for prostate) was close to CIEDs, which makes irradiation dangerous without a carefully calculated dose received by devices and leads. Thus, we selected only nine patients (excluding patients with prostate cancer) to compare the results obtained with and without the MDT method. In case of prostate cancer, induced activity could play a role, but CT scans of these patients did not have CIEDs, and it was impossible to test the method.

We conducted a radiotherapy planning in Eclipse ${ }^{\mathrm{TM}}$ Treatment Planning System, version 11.0 (Varian, Palo Alto, Canada), also applying three-dimensional conformal radiation therapy (3D-CRT), intensity-modulated radiation therapy (IMRT), volumetric-modulated arc therapy (VMAT) and stereotactic body radiation therapy (SBRT) irradiation techniques. We used photon radiotherapy on different linear accelerators: Clinac $600 \mathrm{C}^{\circledR}$, Clinac $2100 \mathrm{CD}^{\circledR}$, Clinac iX ${ }^{\circledR}$, TrueBeam ${ }^{\circledR}$ (all produced by Varian) and Elekta Synergy ${ }^{\circledR}$. In this experiment, we analyzed the influence of the MDT method on plan parameters.

Before radiotherapy planning, it is important to check the warranty period of 
devices provided in their documentation. Most manufacturers guarantee the working lifespan of 5 years. With regard to this information, we divided all implantable devices into several groups during our experiment: $90 \%$ of devices had been working for 5 years or less, and only $10 \%$ had been implanted for more than 5 years. During a warranty period, all devices should work in a proper way without any random errors, which is true for most devices used in the experiment. All parameters of our irradiation plans are presented in Tab. 1.

At the first stage of our study, we made an irradiation plan for nine cancer patients with PMs and ICDs without applying the MDT method. After contouring PTV, critical organs and devices, we selected energy and irradiation techniques. As a result, we calculated the doses received by CIEDs and leads. At the second stage, we used the same CT scans but also applied the MDT method. We recontoured CIEDs and pacing leads in a new manner, and recalculated the same plan in a new CTMDT. As a result, we calculated the new doses received by $\mathrm{PMs} / \mathrm{ICD}$ and pacing leads. We noticed that contouring became much easier due to the high quality of CT scans. Finally, the data obtained with and without the MDT method were compared and analyzed.

\section{Results and Discussion}

The doses received by CIEDs and pacing leads are presented in Tab. 2 and 3, respectively, where Dwithout is the dose before MDT application and Dwith is the dose after use of MDT. Additionally, using the formula, we calculated the inaccuracy associated with metal artifacts and their influence on the dose in the CIEDs and pacing leads, where total dose (Dtotal) is a total dose received by the PTV and (Dwithout - Dwith) is a difference between doses received by devices without and with the deletion method.

Inaccuracy, $\%=\frac{\text { (Dwithout }- \text { Dwith) }}{\text { Dtotal }} \times 100 \%$

The largest malfunction in determining the maximum dose received by CIEDs was observed in 3D-CRT plan for

Tab. 1. Irradiation plan parameters for individual patients.

\begin{tabular}{|l|c|c|c|c|}
\hline $\begin{array}{c}\text { Patient's } \\
\text { number }\end{array}$ & $\begin{array}{c}\text { Tumor } \\
\text { localization } \\
\text { breast and } \\
\text { lymph nodes }\end{array}$ & $\begin{array}{c}\text { Irradiation } \\
\text { technique }\end{array}$ & $\begin{array}{c}\text { Linear } \\
\text { accelerator }\end{array}$ & $\begin{array}{c}\text { Dose in PTV } \\
\text { (Dtotal), Gy }\end{array}$ \\
\hline № 1 & 3D-CRT & Clinac600C & 50 \\
\hline № 2 & esophaguse & 3D-CRT & Clinac2100CD & 35 \\
\hline № 3 & head and neck & IMRT, VMAT & $\begin{array}{c}\text { Clinac2100CD } \\
\text { Clinac iX }\end{array}$ & 70 \\
\hline № 4 & head and neck & 3D-CRT & Synergy & 45 \\
\hline № 5 & breast & 3D-CRT & Clinac iX & 46 \\
\hline № 6 & lungs & VMAT (SBRT) & TrueBeam & 40 \\
\hline № 7 & lungs & VMAT & TrueBeam & 35 \\
\hline № 8 & breast & 3D-CRT & Clinac iX $^{\circledast}$ & 20 \\
\hline № 9 & & & & 50 \\
\hline
\end{tabular}

3D-CRT - three-dimensional conformal radiation therapy, IMRT - intensity-modulated radiation therapy, VMAT - volumetric-modulated arc therapy, SBRT - stereotactic body radiation therapy, PTV - planning target volume, Dtotal - total dose, Gy - Gray

Tab. 2. The doses received by CIEDs without and with MDT application and the related inaccuracies.

\begin{tabular}{|c|c|c|c|c|}
\hline $\begin{array}{l}\text { Patient's } \\
\text { number }\end{array}$ & Dtotal, Gy & Dwithout, Gy & Dwith, Gy & $\begin{array}{c}\text { Inaccuracy } \\
\%\end{array}$ \\
\hline № 1 & 50 & 0.79 & 2.38 & 3.18 \\
\hline № 2 & 35 & 0.92 & 0.95 & 0.09 \\
\hline № 3 & 45 & 0.10 & 0.36 & 0.58 \\
\hline № 4 & 70 & 5.56 & 4.42 & 1.63 \\
\hline № 5 & 46 & 0.86 & 1.02 & 0.35 \\
\hline № 6 & 40 & 2.06 & 2.38 & 0.80 \\
\hline № 7 & 35 & 0.14 & 0.15 & 0.03 \\
\hline № 8 & 20 & 1.32 & 1.35 & 0.15 \\
\hline № 9 & 50 & 0.44 & 0.11 & 0.66 \\
\hline
\end{tabular}

CIEDs - cardiac implantable electronic devices, MDT - Metal Deletion Technique, Dtotal - total dose, Dwithout - dose before MDT application, Dwith - dose after MDT application, Gy - Gray

breast and lymph node irradiation and constituted approximately $3.18 \%$. The problem is that breast and lymph nodes are located too close to CIEDs, and both pacing leads and incorrect contouring can result in serious miscalculation of doses. It is obvious though that an underestimated dose is much more dangerous than an overestimated one.
Analyzing the doses received by leads the main uncertainty introduced in the definition of medium dose and reach $3.70 \%$ of the total dose during esophagus irradiation. The wires leading from the device to the heart are located very close to the esophagus, so this type of cancer requires more care and attention for these patients. Great amounts of 
Tab. 3. The doses received by pacing leads without and with MDT application and the related inaccuracies.

\begin{tabular}{|l|c|c|c|c|}
\hline $\begin{array}{l}\text { Patient's } \\
\text { number }\end{array}$ & Dtotal, Gy & Dwithout, Gy & Dwith, Gy & $\begin{array}{c}\text { Inaccuracy, } \\
\%\end{array}$ \\
\hline № 1 & 50 & 1.02 & 0.42 & 1.20 \\
\hline № 2 & 35 & 4.91 & 3.61 & 3.70 \\
\hline № 3 & 45 & 6.09 & 6.17 & 0.20 \\
\hline № 4 & 70 & 18.48 & 20.91 & 3.50 \\
\hline № 5 & 46 & 0.73 & 0.23 & 1.10 \\
\hline № 6 & 40 & 1.36 & 1.25 & 0.30 \\
\hline № 7 & 35 & 1.10 & 0.99 & 0.30 \\
\hline № 8 & 20 & 1.54 & 1.69 & 0.70 \\
\hline № 9 & 50 & 0.51 & 0.46 & 0.10 \\
\hline
\end{tabular}

MDT - Metal Deletion Technique, Dtotal - total dose, Dwithout - dose before MDT application, Dwith - dose after MDT application, Gy - Gray
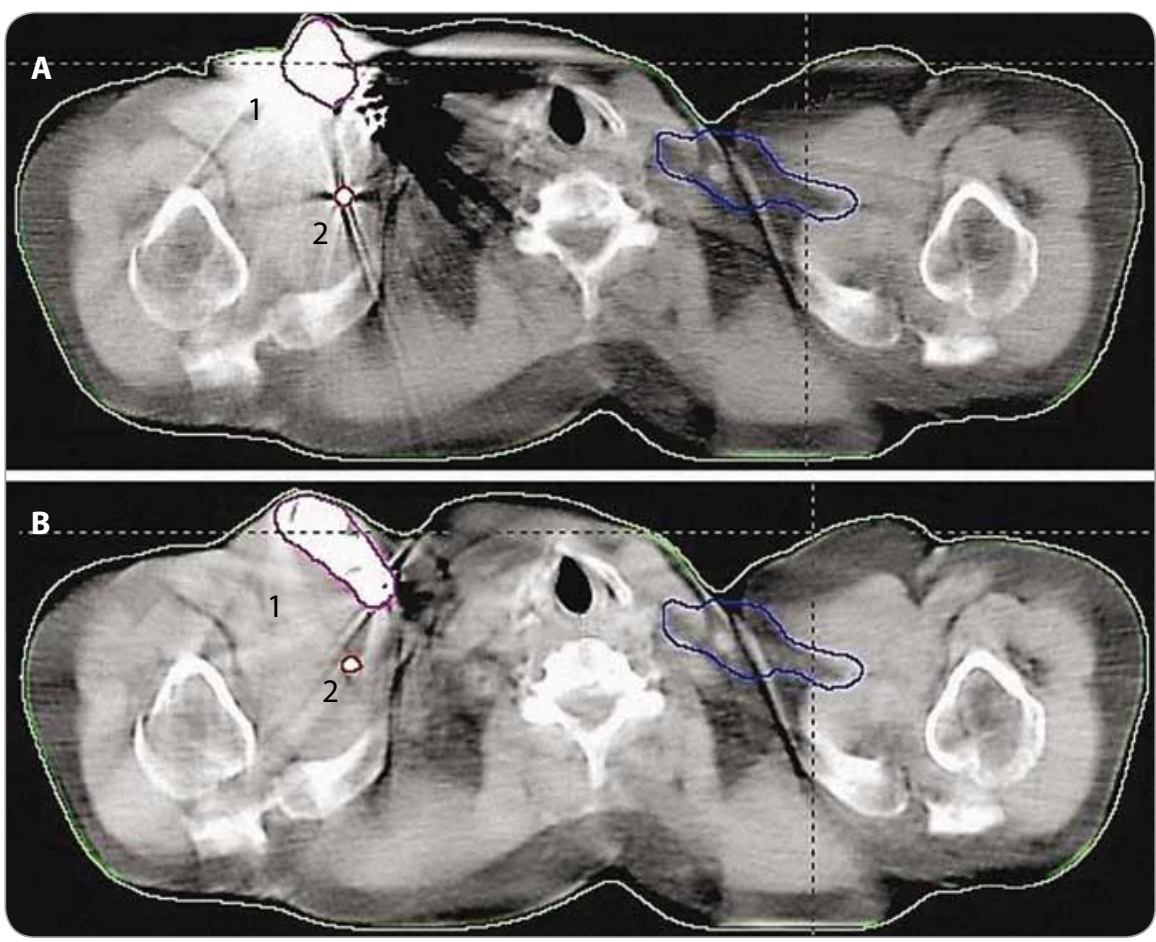

Fig.1. CT scans with (a) and without (b) metal artifacts, where 1 and 2 correspond to the cardiac device and leads respectively.

ionizing radiation reaching the leads can cause interferences, which distort the signals transmitted from the ICDs/PMs to the heart. It can be dangerous for pacing-dependent patients. There are also no data concerning the influence of radiotherapy on pacing leads during the procedure. Thus, such a study can be of some interest for future researches.

It is well known that modern CIEDs rely on complementary metal oxide semiconductors used for integrated circuits. If a large dose of radiation reaches the devices within a single layer of CT scan, it can affect semiconductor

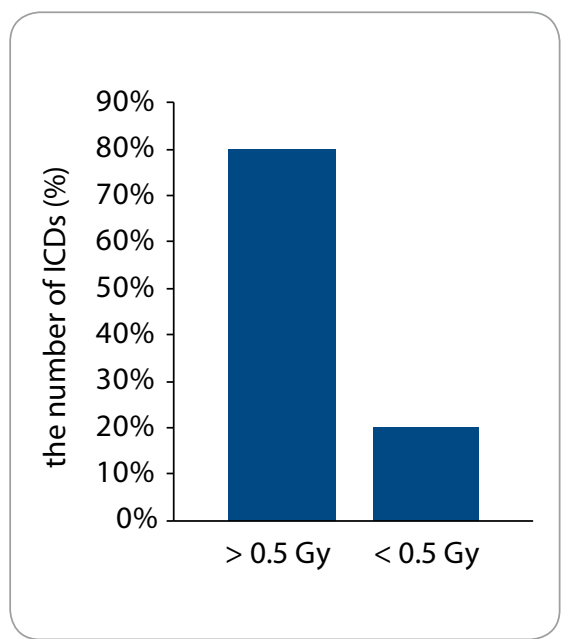

Graph 1. The number of ICDs received more or less than 0.5 Gy during radiotherapy.

ICDs - implantable cardioverter-defibrillators, Gy - Gray

device components. Therefore, it is necessary to take into account maximum doses. In case of pacing leads, there are no such components, and even a mean dose can distort data signals.

According to the CT scans without and with application of the MDT method (Fig. 1) a precise contouring of CIEDs and leads is not possible without application of this method. Moreover, such artifacts can interfere with the PTV, which can cause a lack of tumor irradiation.

The study proved that in case of breast and lymph nodes (patient №1), the dose received by PMs without the MDT method was less than $2 \mathrm{~Gy}$, whereas with the MDT method it was more than 2 Gy. According to European guidelines $[5,7,8]$, patients who received a dose more than 2 Gy fall into a medium risk group. Nowadays, 2 Gy is considered to be a boundary value for planning made by a physicist. It is evident that oncological patients depend on the management of radiation. In such cases, it is necessary to apply the MDT method.

Considering PMs and ICDs on an individual basis, we must note that a dose for PMs has become $1.15 \%$ more accurate, whereas a dose for ICDs has become only $0.58 \%$ better after applying the MDT method. However, PMs are implanted more often and the dose underestimation is more likely to 
happen. Thus, it is necessary to apply the MDT method while providing therapy for patients with implantable PMs to avoid possible malfunctions. As for ICDs, they are more sophisticated and can automatically defibrillate the heart by monitoring the patient's heart rate and deliver appropriate electrical therapy. There is a recommendation of a lower radiotherapy tolerance dose. According to some sources, the estimated cumulative radiotherapy dose to ICD should not exceed 0.5 Gy [7]. Based on these data, we divided all the implantable devices in our experiment (Graph 1). It was found that $80 \%$ of cardioverter-defibrillators were irradiated with a dose exceeding $0.5 \mathrm{~Gy}$. The MDT method allows taking into account this fact and more accurately controls the dose received by the ICDs. However, a tolerant dose of $0.5 \mathrm{~Gy}$ is not currently used in practice in the Czech Republic.

\section{Conclusion}

The results obtained in this experiment confirm the need to use MDT method for removal of artifacts in CT images. Such an approach to the planning of radiation therapy can improve its quality and reduce the likelihood of malfunctions in devices.

The greatest error in determining the dose received by CIEDs and pacing leads is more than $3 \%$ of the total dose. It can significantly change the patient's treatment plan and influence the safe management of patients with a CIED receiving radiotherapy.

\section{References}

1. Grant JD, Jensen GL, Tang C et al. Radiotherapy-induced malfunction in contemporary cardiovascular implantable electronic devices: clinical incidence and predictors.
JAMA Oncol 2015; 1(5): 624-632. doi: 10.1001/jamaoncol.2015.1787

2. Zweng A, Schuster R, Hawlicek R et al. Life-threatening pacemaker dysfunction associated with therapeutic radiation: a case report. Angiology 2009; 60(4): 509-512. doi: 10.1177/0003319708315305.

3. Rodriguez F, Filimonov A, Henning A et al. Radiation-induced effects in multiprogrammable pacemakers and implantable defibrillators. Pacing Clin Electrophysiol 1991; 14(12): 2143-2153.

4. Zaremba T, Jakobsen AR, Thøgersen AM et al. The effect of radiotherapy beam energy on modern cardiac devices: an in vitro study. Europace 2014; 16(4): 612-616. doi: 10.1093/europace/eut249.

5. Gauter-Fleckenstein B, Israel CW, Dorenkamp M et al. DEGRO/DGK guideline for radiotherapy in patients with cardiac implantable electronic devices. Strahlenther Onkol 2015; 191(5): 393-404. doi: 10.1007/s00066-015-0817-3.

6. Boas FE, Fleischmann D. CT artifacts: causes and reduction techniques. Imaging Med 2012; 4(2): 229-240.

7. Beardmore C. Management of cancer patients receiving radiotherapy with a cardiac implanted electronic device: a clinical guideline. London: The Society of Radiographers 2015: 1-17.

8. Hurkmans CW, Knegjens JL, Oei BS et al. Management of radiation oncology patients with a pacemaker or ICD: a new comprehensive practical guideline in The Netherlands. Dutch Society of Radiotherapy and Oncology (NVRO). Radiat Oncol 2012; 7: 198. doi: 10.1186/1748-717X-7-198. 